consequence of a subtle alteration of the sleep structure by an abnormally high sympathetic activity.

\section{Vernet*, S. Redolfi*, , V. Attali*,\#, E. Konofal*, A. Brion*, E. Frija-Orvoen*, M. Pottier*, T. Similowski" and I. Arnulf ${ }^{*}, \#$ *Sleep Disorders Unit, UMR 975, National Reference Centre for Narcolepsy and Hypersomnia, and "Dept of Respiratory and Intensive Care Medicine and ER10 Pierre and Marie Curie University, Pitié-Salpêtrière Hospital, Assistance Publique Hôpitaux de Paris, Paris, France.}

Correspondence: I. Arnulf, Unité des Pathologies du Sommeil, Hôpital Pitié-Salpêtrière, 47-83 Boulevard de l'Hôpital, 75651 Paris Cedex 13, France. E-mail: isabelle.arnulf@psl.aphp.fr
Statement of Interest: Statements of interest for V. Attali, E. FrijaOvoen and M. Pottier can be found at www.erj.ersjournals.com/ site/misc/statements.xhtml

\section{REFERENCES}

1 Vernet C, Redolfi S, Attali V, et al. Residual sleepiness in obstructive sleep apnoea: phenotype and related symptoms. Eur Respir J 2011; 38: 98-105.

2 Heart rate variability. Standards of measurement, physiological interpretation, and clinical use. Task Force of the European Society of Cardiology and the North American Society of Pacing and Electrophysiology. Eur Heart J 1996; 17: 354-381.

3 Lombardi C, Parati G, Cortelli P, et al. Daytime sleepiness and neural cardiac modulation in sleep-related breathing disorders. J Sleep Res 2008; 17: 263-270.

\title{
Viral wheezing is virus specific and not just host specific
}

\section{To the Editors:}

In a recent issue of the European Respiratory Journal, STRIPPOLI et al. [1] reported their interesting findings on exclusive viral wheezing versus allergic wheezing in a large population-based, prospectively followed cohort including 4,102 children at $1 \mathrm{yr}$ and 1,858 children at 9 yrs of age. The parents reported current wheezing in $36,20,16$ and $16 \%$ of the children at age $1,4,6$ and 9 yrs, respectively. The study showed considerable agerelated, parent-reported changes in the relative importance of triggers for wheezing in children. The proportion of infection decreased constantly from $94.1 \%$ (at age $1 \mathrm{yr}$ ) to $81.0 \%$ (at age $9 \mathrm{yrs}$ ) and the proportion of allergic wheeze increased constantly from $7.5 \%$ (at age $1 \mathrm{yr}$ ) to $62.4 \%$ (at age $9 \mathrm{yrs}$ ). The proportion of exercise as a trigger for wheezing was rather similar at all ages, being lowest (35.5\%) at age $1 \mathrm{yr}$ and highest $(48.6 \%)$ at age 6 yrs.

The association between exercise and allergens as triggers for wheezing was significant at age 1, 4 and 6 yrs, and between exercise and infection at age 1, 6 and 9 yrs. Conversely, allergens and infection were not associated at any age; the association was even negative (OR 0.54; $\mathrm{p}=0.051$ ) at age 6 yrs. Thus, the authors confirmed positive associations between exercise and allergens, and between exercise and infection as triggers for wheezing, but there were no positive associations between allergens and infection at any age. The authors concluded that exclusive viral wheezing and allergen-induced, multiple-trigger wheezing are distinct disease entities presenting in genetically different children [1].

The findings are in agreement with those from post-bronchiolitis studies [2], and with clinical experience as well. If bronchiolitis is defined as wheezing-associated respiratory infection at age $<24$ months, post-bronchiolitis wheezing during subsequent viral infections is common. In long-term, prospective postbronchiolitis studies, $60 \%$ of the former bronchiolitis patients have wheezed at age $2-3$ yrs and $15-40 \%$ have had doctordiagnosed asthma at school age [2]. However, if bronchiolitis has been caused by respiratory syncytial virus (RSV) [2], or has taken place at age $<6$ months when RSV is the predominant causative agent [3], later asthma seems not to be substantially more common than in the non-selected population. Doctor-diagnosed asthma was present at age 6.5 yrs in $12.7 \%$ of the 166 children hospitalised for bronchiolitis at age $<6$ months. The figure was $8.2 \%$ in the former RSV patients versus $24 \%$ in the former nonRSV patients [3].

Asthma in parents and atopy in infants are the most strong and consistently documented risk factors for later chronic asthma after bronchiolitis or early-life wheezing [2]. In addition, the virus that is associated with the first wheezing episode may play an important role, either by modifying the course or outcome of early-life wheezing, or by picking up those who are prone to asthma and actually have their first asthma episode in infancy. Rhinovirus-induced wheezing, in particular, seems to be associated with atopy, eosinophilia and later asthma [4]. Bocavirus is nearly equally as common as RSV and rhinovirus in wheezing infants and young children, but its role as an independent aetiological agent in children with respiratory infection and its association with later outcomes are still unknown [5]. Thus, children with viral wheezing, even those with exclusively viral wheezing, merely form a genetically heterogeneous, rather than a genetically homogenous, group. In future studies, the group of children with viral wheezing should be analysed as stratified into virus-specific categories allowing the evaluation of the interaction between viral and genetic factors, such as atopy or components of innate immunity.

The observation of STRIPPOLI et al. [1] that there was no association between allergens and symptomatic infections as triggers for wheezing in children is important and provides evidence that exclusive viral wheezing is its own disease entity 
with its own genetics. However, the great majority of viral infections are nonsymptomatic and wheezing may be the only symptom of respiratory viral infection. Prospective postbronchiolitis follow-up studies with virus-specific diagnoses and virus-specific outcomes available have provided evidence that viral wheezing is also a virus-specific phenomenon, not only a host-specific phenomenon. There may be different viruses that trigger wheezing in children with exclusively viral wheezing and in children with allergic wheezing.

\section{Korppi}

Paediatric Research Center, Tampere University and University Hospital, Tampere, Finland.

Correspondence: M. Korppi, Paediatric Research Center, Tampere University Hospital, Tampere 33140, Finland. E-mail: matti.korppi@uta.fi

Statement of Interest: None declared.

\section{REFERENCES}

1 Strippoli MP, Spycher BD, Pescatore AM, et al. Exclusive viral wheeze and allergic wheeze: evidence for discrete phenotypes. Eur Respir J 2011; 38: 472-474.

2 Piippo-Savolainen E, Korppi M. Wheezy babies: wheezy adults? Review on long-term outcome until adulthood after early childhood wheezing. Acta Paediatr 2008; 97: 5-11.

3 Koponen P, Helminen M, Paassilta M, et al. Preschool asthma after bronchiolitis in infancy. Eur Respir J 2012; 39: 76-80.

4 Kotaniemi-Syrjänen A, Vainionpää R, Reijonen TM, et al. Rhinovirusinduced wheezing in infancy-the first sign of childhood asthma? J Allergy Clin Immunol 2003; 111: 66-71.

5 Allander T, Jartti T, Gupta S, et al. Human bocavirus and acute wheezing in children. Clin Infect Dis 2007; 44: 904-910.

DOI: $10.1183 / 09031936.00150811$ 